\title{
TRATAMENTO DE EFLUENTES E PRODUÇÃO DE ÁGUA DE REÚSO PARA FINS AGRÍCOLAS
}

\author{
D. M. TORRES*, S. S. NASCIMENTO, J. F. SOUZA, J.O. FREIRE \\ Instituto Federal de Educação, Ciência e Tecnologia do Rio Grande de Norte \\ dayana.torres@ifrn.edu.br
}

Artigo submetido em 25/11/2019 e aceito em 11/12/2019

DOI: $10.15628 /$ holos.2019.9192

\section{RESUMO}

A agricultura é o setor que mais consome água no planeta, cerca de $70 \%$ da água potável, o que aponta para a necessidade de buscar meios eficazes para a diminuição desse uso. $O$ efluente mais adequado para a aplicação na agricultura é o esgoto doméstico, devido à sua composição e aos seus valores nutricionais. Desse modo, o referido trabalho tem como objetivo avaliar o tratamento de efluentes e a produção de água de reúso para fins agrícolas no campus do IFRN de São Paulo do Potengi/RN, Brasil. Para avaliação da qualidade do tratamento de esgotos, foram realizadas coletas dos esgotos bruto e tratado em uma das Estações de Tratamento de Esgoto (ETEs) do referido campus, entre
\end{abstract}

os meses de julho e dezembro de 2018. Para isso, foram analisadas as propriedades físico-químicas e microbiológicas do efluente por meio de parâmetros, como: $\mathrm{pH}$, temperatura, condutividade elétrica, alcalinidade total, sólidos suspensos totais, DQO, nitrogênio amoniacal, nitrogênio orgânico, NTK, sódio, cálcio, magnésio e coliformes termotolerantes, todos segundo APHA et al. (2017). Espécimes de milho (Zea mays) foram irrigadas com efluente tratado em diferentes dosagens na horta do laboratório do campus e obteve-se resultados favoráveis para a utilização do efluente na irrigação dessa cultura.

PALAVRAS-CHAVE: Tratamento de efluentes, reúso agrícola, esgoto doméstico.

\section{WASTE TREATMENT AND WASTE PRODUCTION FOR AGRICULTURAL PURPOSES}

\begin{abstract}
Agriculture is the most water-consuming sector on the planet, about $70 \%$ of drinking water, which points to the need to find effective ways to reduce its use. The most suitable effluent for agricultural application is domestic sewage, due to its composition and nutritional values. Thus, this work aims to evaluate the effluent treatment and the production of reused water for agricultural purposes in the IFRN campus of São Paulo do Potengi / $\mathrm{RN}$, Brazil. To assess the quality of sewage treatment, raw and treated sewage collections were carried out at one of the campus sewage treatment plants (ETEs) between July
\end{abstract}

and December 2018. For this purpose, the physical properties were analyzed. and microbiological effects of the effluent using parameters such as $\mathrm{pH}$, temperature, electrical conductivity, total alkalinity, total suspended solids, COD, ammonia nitrogen, organic nitrogen, NTK, sodium, calcium, magnesium and thermotolerant coliforms, all according to APHA et al. (2017). Maize specimens (Zea mays) were irrigated with effluent treated at different dosages in the campus laboratory garden and favorable results were obtained for the use of effluent to irrigate this crop. 


\section{INTRODUÇÃO}

A disponibilidade e a qualidade dos recursos hídricos têm se agravado nas últimas décadas, sobretudo em regiões semiáridas do Nordeste brasileiro. O aumento populacional nas áreas urbanas reflete diretamente nas pressões sobre os mananciais, já que se tem acréscimo na demanda de água para abastecimento e aumento da produção de efluentes, que, em sua grande maioria, chegam aos mananciais com elevadas concentrações de nutrientes que contribuem com o processo de eutrofização.

Nesse sentido, o reúso de águas pode trazer benefícios econômicos, sociais e ambientais para as comunidades em que se insere, sendo uma alternativa mais sustentável para a disposição dos efluentes tratados. Sendo assim, o esgoto doméstico é uma alternativa de uso potencial na agricultura, pois águas de melhores qualidades podem ser utilizadas para fins mais nobres, como, por exemplo, para o consumo humano e/ou para a dessedentação de animais, como preconiza a Política Nacional de Recursos Hídricos, por meio da Lei no 9.433 de 1997.

O Brasil é um dos maiores produtores de alimentos do mundo, por razões diversas, como seu clima variado, suas dimensões continentais, seu solo fértil e sua grande disponibilidade hídrica (12,3\% da água doce mundial). Apesar disso, existe, nesse território, uma variação espacial e temporal, em que a Região Nordeste, mais especificamente a região do semiárido nordestino, apresenta a porcentagem de 3,3\% dos recursos hídricos do país, menor percentual entre as 5 regiões (ANA, 2019).

Em função disso, o semiárido brasileiro é acometido por uma crise hídrica (FELIPE; CARVALHO; ROCHA, 2004), proveniente da irregular distribuição dos recursos hídricos em função das condições edafoclimáticas locais e da ineficiente gestão desses recursos, que implicam em sua racionalização, priorizando o consumo humano. Assim, no entrave ao desenvolvimento das atividades antrópicas na região em questão, torna-se necessário buscar mecanismos de enfrentamento das referidas adversidades naturais.

De acordo com o Instituto Brasileiro de Geografia e Estatística - IBGE (2008), cerca de 19\% da população brasileira vive na zona rural, o que equivale a mais de 31 milhões de pessoas, e a maior parte dessas localidades lança seus efluentes in natura nos corpos hídricos ou no solo, comprometendo a qualidade da água utilizada para abastecimento, para irrigação e para recreação (TONETTI et al., 2010). 
Além disso, aproximadamente $70 \%$ do uso mundial de água, incluindo o desvio dos rios e o bombeio do subsolo, é utilizado para irrigação agrícola. A reutilização das águas residuárias tratadas para esse fim reduz a quantidade que seria extraída das fontes naturais e reduz a descarga desses efluentes diretamente nos mananciais superficiais. De acordo com o Ministério da Agricultura, Pecuária e Abastecimento (BRASIL, 2019), a agricultura brasileira cresceu, entre os anos de 1975 e 2018, em média, 3,36\% ao ano. Essa taxa é superior a de países como Argentina, Austrália e China. Rocha, Silva e Barros (2010) comentam que o reúso dos efluentes domésticos poderia, então, ser uma alternativa para as demandas de água e de nutrientes na agricultura.

Nesse sentido, o presente trabalho objetivou avaliar o tratamento e o reúso agrícola de águas residuárias produzidas no campus do IFRN de São Paulo do Potengi.

\section{REVISÃO BIBLIOGRÁFICA}

Atualmente, uma das grandes dificuldades existentes na agricultura é conseguir produzir mais e consumir uma menor quantidade de água, principalmente em regiões de clima seco. Em regiões áridas e/ou semiáridas, por sua vez, o montante de água consumido pelas culturas irrigadas ultrapassa os $70 \%$ do total de água potável disponível (MORISON et al., 2008). Desse modo, além da preservação da imensa quantidade de água que é utilizada na irrigação, também se pode levar em conta a quantidade de fertilizantes que pode ser dispensada com o aproveitamento de águas residuárias na irrigação (OLIVEIRA, 2012), tendo em vista que a quantidade de fertilizante por área plantada no Brasil passou de $70 \mathrm{~kg}$ por hectare em 1992 para mais de $150 \mathrm{~kg} / \mathrm{ha}$ em 2010. Durante o período, o uso de produtos como esse, consumidos no país, chegou a atingir um pico de 160 kg/ha em 2007 (IBGE, 2019).

Nesse contexto, o efluente considerado mais adequado para a aplicação na agricultura é o esgoto doméstico, principalmente os esgotos tratados, devido à sua composição e aos seus valores nutricionais. O reúso na agricultura também pode ser uma alternativa de fertilizante, tendo em vista que, de acordo com Oliveira (2012), muitas águas residuárias possuem altas concentrações de NPK (nitrogênio, fósforo e potássio). Por outro lado, em virtude da sua composição química, efluentes industriais geralmente não são incompatíveis para o reúso agrícola, porque podem apresentar substâncias tóxicas para o homem e para os animais.

No Brasil, a prática de irrigação agrícola ainda não é regulamentada, o que dificulta a aplicação de efluentes tratados em grande escala. O CNRH (Conselho Nacional de Recursos 
Hídricos) lançou, em 2003, uma minuta de resolução similar à recomendação da Organização Mundial da Saúde, incentivando o uso alternativo de águas de qualidade inferior e estabelecendo os padrões de qualidade dos efluentes para cada modalidade de reúso, o que representou um grande passo na legalização da técnica no país.

Contudo, tal resolução não entrou em vigor e, no ano de 2005, o órgão lançou a Resolução $\mathrm{n}^{\circ}$ 54, que incentiva a prática de reutilização em diversas modalidades, no entanto, sem estabelecer parâmetros específicos para seu emprego (BRASIL, 2005). Não somente no Brasil, mas em muitos outros países, a legislação sobre o reúso é inexistente, muito branda ou muito restritiva e faltam estudos que evidenciem quais são as taxas seguras de aplicação para cada cultura e quais são os reais danos que cada contaminante pode ocasionar ao sistema solo-água-planta (OLIVEIRA, 2012; RIBEIRO, 2013).

As águas de qualidade inferior, como, por exemplo, os esgotos, particularmente os de origem doméstica, águas de drenagem agrícola e águas salobras, devem, sempre que possível, ser consideradas como fontes alternativas para usos menos restritivos. Isso ajuda os produtores rurais a manterem seus rebanhos em períodos de estiagens e a economizarem gastos com água potável que pode ser utilizada para finalidades mais nobres e, consequentemente, ajudar na preservação do meio ambiente e de seus recursos.

Para que isso seja possível, as águas residuárias tratadas e destinadas ao reúso agrícola devem ser avaliadas sob os aspectos de presença de sódio, salinidade, excesso de nutrientes e, sobretudo, sob os aspectos sanitários: bactérias, cistos de protozoários, ovos de helmintos e vírus que criam graves problemas de saúde pública, uma vez que acarretam em enfermidades (METCALF \& EDDY, 2017).

Desse modo, em períodos de chuvas, toda a região se mantém em crescimento e, em períodos de estiagem, a plantação, quando irrigada com águas residuárias, continua sendo produzida, dando perspectiva de plantação ao homem do campo o ano inteiro. Essa cultura agrícola, em geral, pode ser de beneficiamento direto, como, por exemplo, na plantação de milho, de mamão, de cana de açúcar e outros, ou ainda de beneficiamento indireto, por meio do qual a cultura será destinada para alimentação do gado de corte e leiteiro, na produção da palma forrageira, do sorgo, do capim elefante e demais cultivares.

Segundo Hespanhol (2013), o uso de tecnologias apropriadas para o desenvolvimento dessas fontes se constitui hoje, em conjunção com a melhoria da eficiência do uso e o controle da demanda, como estratégia básica para a solução do problema da falta universal de água. Ainda de 
acordo com esse autor, durante as duas últimas décadas, o uso de esgotos para irrigação de culturas aumentou significativamente devido aos seguintes fatores:

- dificuldade crescente de identificar fontes alternativas de águas para irrigação;

- custo elevado de fertilizantes;

- segurança de que os riscos de saúde pública e impactos sobre o solo são mínimos, se as precauções adequadas são efetivamente tomadas;

- custos elevados dos sistemas de tratamento, necessários para descarga de efluentes em corpos receptores;

- aceitação sociocultural da prática do reúso agrícola e reconhecimento, pelos órgãos gestores de recursos hídricos, do valor intrínseco da prática.

\section{METODOLOGIA}

\section{1. Área de estudo}

Este estudo foi desenvolvido no campus do Instituto Federal de Educação, Ciência e Tecnologia do Rio Grande do Norte (IFRN) de São Paulo do Potengi, situado a 71 km da capital Natal-RN, cujas coordenadas geográficas são: latitude: 05 53' 42" S; longitude: 35o 45' 46" W; e altitude: 91m ao nível do mar (IBGE, 2019). Na referida instituição de ensino, existem três sistemas de tratamento de esgotos, a saber:

- ETE-1: atende ao bloco de aulas (Bloco A) e auditório;

- ETE-2: atende ao bloco dos laboratórios, refeitório e setor de saúde;

- ETE-3: atende o centro de lazer e esportes.

As ETE são pré-fabricadas e compostas por unidade de tratamento preliminar (grade, caixa de areia e medidor de vazão) e sistema de tratamento compacto composto por tanque séptico seguido de filtro submerso anaeróbio (Figura 1). O efluente tratado é infiltrado no solo através de sumidouro. 


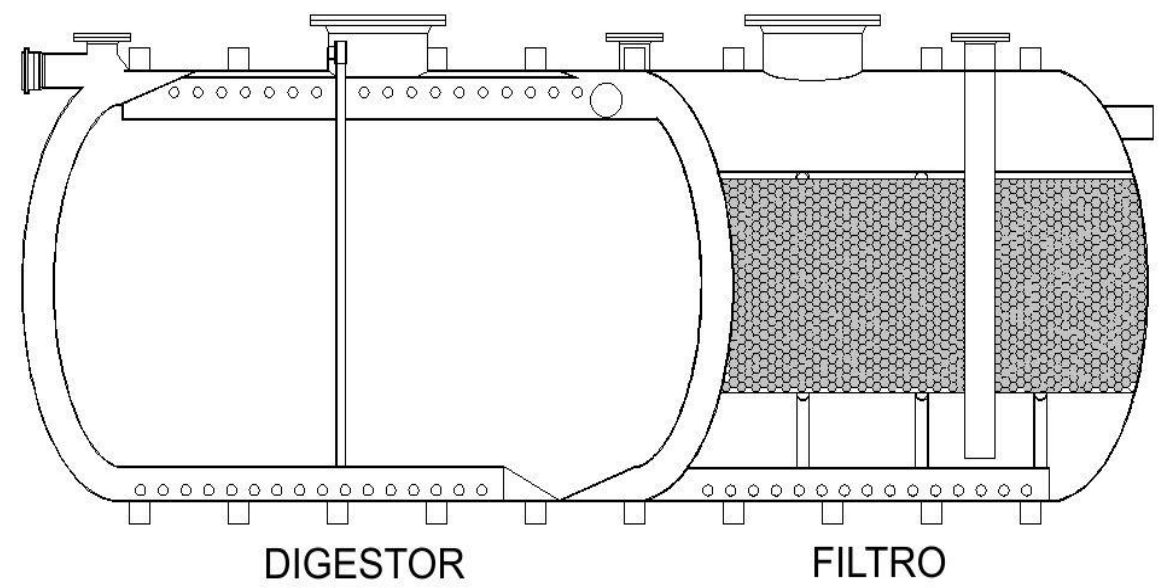

Figura 1: Corte longitudinal do tanque séptico seguido de filtro anaeróbio.

O diagnóstico operacional das ETEs foi realizado a partir de visitas in loco para avaliação dos aspectos de manutenção e operação nas 3 ETEs, por meio das quais foi avaliada a presença ou ausência de tratamento preliminar, a existência de vazamentos, a limpeza externa e interna das unidades e a disposição final dos efluentes tratados. Todos esses aspectos são relevantes para avaliar a qualidade do tratamento e, consequentemente, do efluente tratado. Nesta pesquisa, utilizou-se apenas o efluente tratado proveniente da ETE-1 (Figura 2), devido aos problemas operacionais nas demais estações que impossibilitaram o monitoramento.

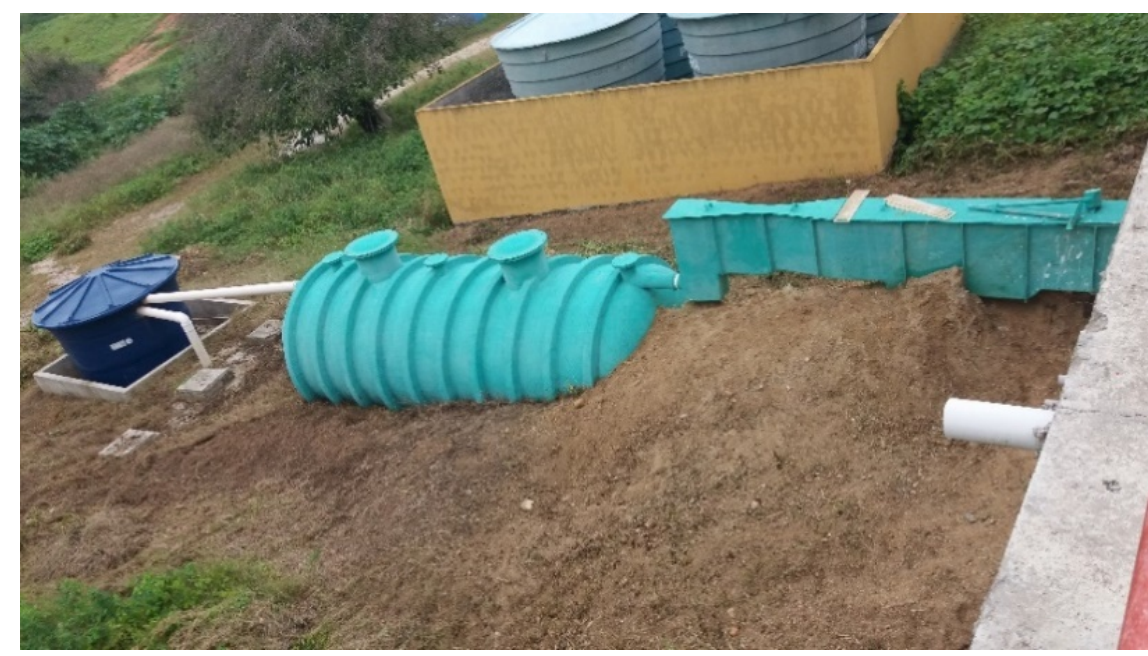

Figura 2: ETE-1 que trata os esgotos produzidos no bloco de aulas e auditório.

A caracterização do esgoto bruto e do tratado foi realizada por meio de 9 coletas, entre os meses de julho e dezembro de 2018 , com frequência quinzenal às 8 h e 30 minutos, que é o período 
em que se tem os maiores picos de vazão. Os parâmetros avaliados estão apresentados na Tabela 1, com seus respectivos métodos e referências.

Tabela 1: Variáveis avaliadas, métodos e referências.

\begin{tabular}{|c|c|c|c|}
\hline Variáveis & Unidade & Método & Referência \\
\hline Temperatura & $\stackrel{\circ}{ } \mathrm{C}$ & $\begin{array}{l}\text { Termômetro com filamento de } \\
\text { mercúrio }\end{array}$ & \multirow{15}{*}{$\begin{array}{l}\text { APHA, AWWA e } \\
\text { WEF (2017) }\end{array}$} \\
\hline $\mathrm{pH}$ & - & Potenciométrico & \\
\hline $\begin{array}{c}\text { Condutividade } \\
\text { elétrica }\end{array}$ & $\mu \mathrm{S} / \mathrm{cm}$ & Potenciométrico & \\
\hline $\begin{array}{l}\text { Sólidos suspensos } \\
\text { totais }\end{array}$ & $\mathrm{mg} / \mathrm{L}$ & $\begin{array}{l}\text { Gravimétrico - Filtração a vácuo e } \\
\text { secagem a 103ㄷ - 105ㄷ }\end{array}$ & \\
\hline Alcalinidade total & $\mathrm{mgCaCO}_{3} / \mathrm{L}$ & Titulométrico com $\mathrm{H}_{2} \mathrm{SO}_{4}$ & \\
\hline DQO & $\mathrm{mg} / \mathrm{L}$ & Titulométrico - Refluxação fechada & \\
\hline $\begin{array}{l}\text { Nitrogênio } \\
\text { amoniacal }\end{array}$ & $\mathrm{mg} / \mathrm{L}$ & Titulométrico com $\mathrm{H}_{2} \mathrm{SO}_{4}$ & \\
\hline Nitrogênio orgânico & $\mathrm{mg} / \mathrm{L}$ & Digestão e titulação com $\mathrm{H}_{2} \mathrm{SO}_{4}$ & \\
\hline NTK & $\mathrm{mg} / \mathrm{L}$ & Somatório & \\
\hline Fósforo total & $\mathrm{mg} / \mathrm{L}$ & $\begin{array}{l}\text { Espectrofotométrico - digestão } \\
\text { ácida e cloreto estanhoso }\end{array}$ & \\
\hline Ortofosfato solúvel & $\mathrm{mg} / \mathrm{L}$ & $\begin{array}{l}\text { Espectrofotométrico - cloreto } \\
\text { estanhoso }\end{array}$ & \\
\hline Sódio & $\mathrm{mg} / \mathrm{L}$ & Espectrofotometria de chama & \\
\hline Cálcio & $\mathrm{mg} / \mathrm{L}$ & Titulométrico com EDTA & \\
\hline Magnésio & $\mathrm{mg} / \mathrm{L}$ & Titulométrico com EDTA & \\
\hline $\begin{array}{l}\text { Coliformes } \\
\text { termotolerantes }\end{array}$ & $\mathrm{NMP} / 100 \mathrm{~mL}$ & Tubos múltiplos & \\
\hline
\end{tabular}

Para as análises físico-químicas, foram coletados aproximadamente 2 litros de amostra e, para as análises microbiológicas, cerca de 100 mililitros, sendo que estas foram armazenadas em recipientes previamente esterilizados. Após a coleta, as amostras foram acondicionadas em caixa térmica, a uma temperatura média de 4 으 para preservar seus constituintes físico-químicos e microbiológicos. Todos os experimentos foram realizados no Laboratório de Análises de Águas, Efluentes e Solos do IFRN - Campus São Paulo do Potengi.

\subsection{Plantio e irrigação}

Os experimentos de irrigação com efluente tratado foram realizados no período de agosto a novembro de 2018, e as sementes utilizadas foram de milho (Zea mays) - cultivar sertaneja - 
provenientes de um produtor da região. O plantio foi efetuado no dia 16/08/2018 e, para isso, utilizou-se 8 indivíduos plantados em vasos com as dimensões $20 \times 15 \mathrm{~cm}$ e $30 \mathrm{~cm}$ de altura (Figuras 3 e 4).

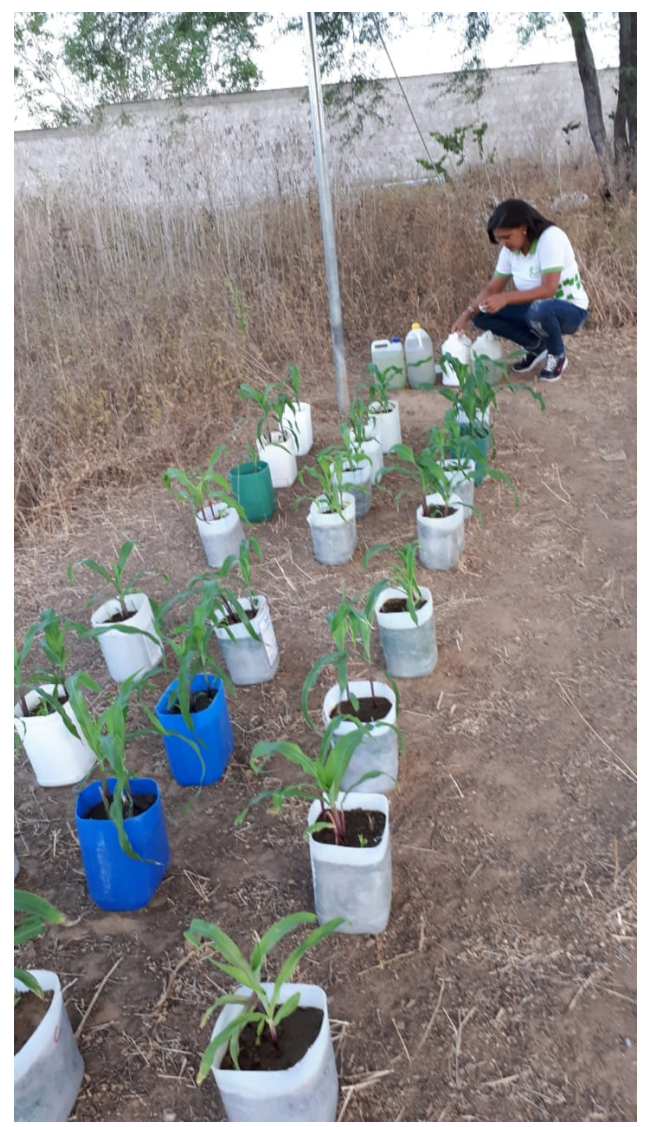

Figura 3: Cultivo de milho no início do processo de irrigação com efluente tratado.

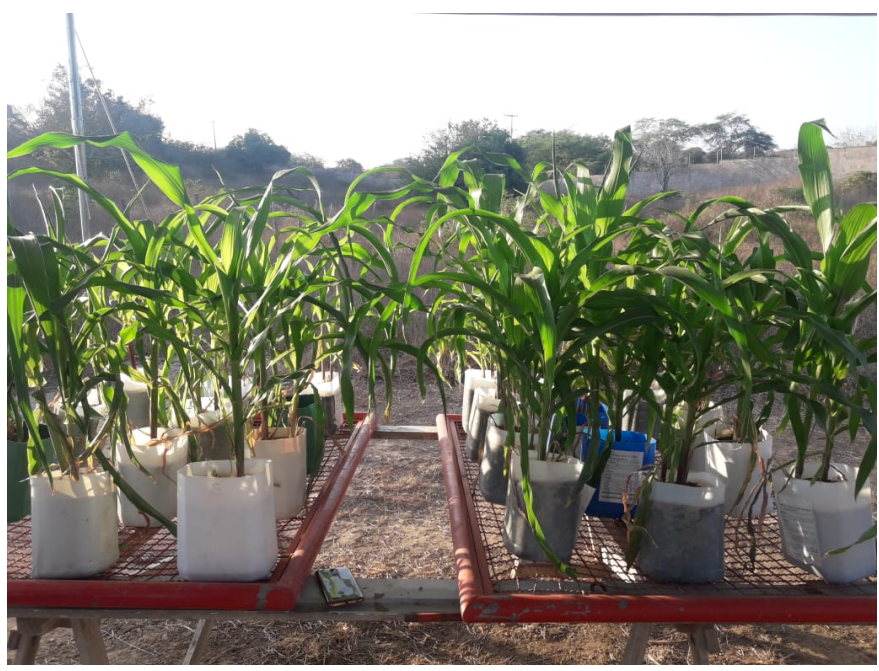

Figura 4: Cultivo de milho no final do processo de irrigação com efluente tratado. 
As irrigações foram realizadas com uso de regador manual e água potável fornecida pela Companhia de Águas e Esgotos do Rio Grande do Norte (CAERN), a partir do efluente tratado da ETE-1 do campus do IFRN de São Paulo do Potengi. O processo de irrigação ocorreu, até o dia 19/11/2018, em dias alternados de 4 indivíduos para cada tipo de água de irrigação (água potável e efluente tratado), em um volume de $550 \mathrm{~mL}$ por dia.

Após as plantas atingirem o estágio de maturidade, avaliou-se a presença e o decaimento bacteriano de microrganismos indicadores de contaminação fecal, nesse caso, os coliformes termotolerantes na parte aérea dos vegetais. Esse procedimento foi realizado sem a adição de qualquer volume de água ou efluente após suspensão da irrigação. Além disso, as análises microbiológicas também foram realizadas nas dependências do Laboratório de Análises de Águas, Efluentes e Solos do IFRN - Campus São Paulo do Potengi. Avaliou-se a concentração de coliformes termotolerantes segundo APHA et al. (2017) no efluente tratado e na parte aérea das plantas irrigadas com $100 \%$ desse efluente, a fim de verificar a segurança sanitária quanto à manipulação dos espécimes de milho.

Para a extração das bactérias do grupo coliformes termotolerantes da parte aérea das plantas, utilizou-se $100 \mathrm{ml}$ de soro fisiológico estéril para lavagem das partes superiores, ou seja, as que não têm contato direto com o solo. Esse procedimento foi realizado ao longo de quatro dias consecutivos, sendo que, a cada dia, um indivíduo era avaliado. Desse modo, a avaliação agronômica das plantas produtoras de milho foi realizada para acompanhar a eficiência da fertirrigação com efluente primário tratado. Verificou-se a altura de planta (AP), com uso de fita métrica/trena métrica, e a massa seca (MS), com uso da estufa.

\section{RESULTADOS E DISCUSSÃO}

A partir das visitas in loco, foi possível constatar que todas as ETEs apresentam tratamento preliminar, o que favorecea remoção de sólidos grosseiros, permite que os reatores anaeróbios não recebam areia ou sólidos de tamanhos elevados e auxilia no tratamento primário do esgoto. Entretanto, foram observados problemas de manutenção que influenciavam na sua operação, como a presença elevada de vegetação no entorno (Figura 5), a ausência de limpeza do tratamento preliminar (Figura 6), e vazamentos em diversos locais das ETEs (Figura 7). 


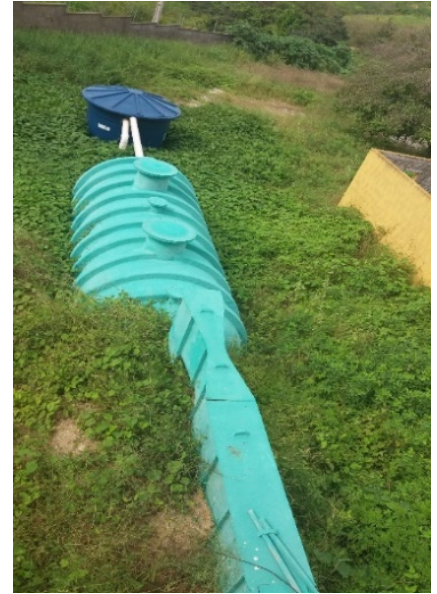

Figura 5: ETE-1 com excesso de vegetação no entorno.

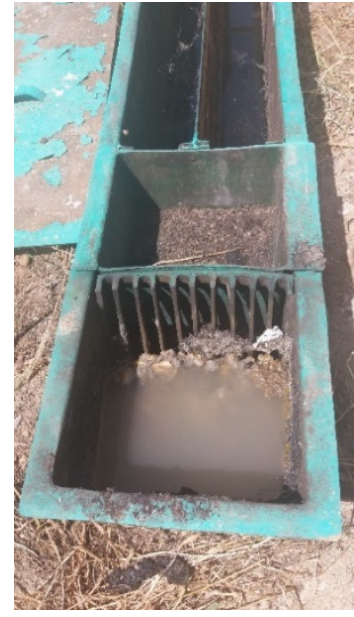

Figura 6: Tratamento preliminar da ETE-2 com obstrução e excesso de gordura e sólidos

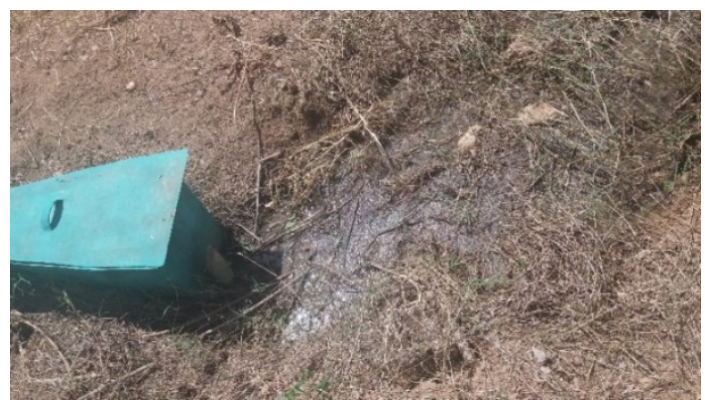

Figura 7: Vazamento no tratamento preliminar da ETE-2.

Em relação à caracterização do esgoto bruto, identificou-se que ele apresenta características tipicamente domésticas e passíveis de serem tratadas por via biológica, tendo como primeira unidade de tratamento um reator anaeróbio, o mesmo tratamento que é utilizado nas ETEs do campus São Paulo do Potengi.

De acordo com Amaral (2015), o pH do esgoto bruto em ETEs do IFRN varia de 7,0 a 8,7, estando o pH obtido em nosso trabalho dentro dessa faixa, que foi de 8,4 . Apesar de ser um valor elevado para esgoto doméstico, que tende à neutralidade, isso é justificado pelo uso excessivo de produtos de limpeza. Ainda de acordo com Amaral (2015), nos esgotos brutos, as medianas de DQO variaram entre $138 \mathrm{mg} / \mathrm{L}$ e $349 \mathrm{mg} / \mathrm{L}$ e, em nosso monitoramento, o valor obtido foi de 408 mg/L, o que é justificável devido ao aumento da carga orgânica, já que em 2015 a população que circulava no campus era inferior à população atual.

Por outro lado, o NTK apresentou concentrações elevadas, conforme se observa na Tabela 3. A concentração média de coliformes termotolerantes no esgoto bruto foi de $3 \times 10^{7} \mathrm{NMP} / 100$ 
$\mathrm{mL}$, semelhante ao obtido para esgoto doméstico bruto. O mesmo comportamento foi verificado em relação aos sólidos suspensos totais, mas o valor de $121 \mathrm{mg} / \mathrm{L}$ é condizente com a característica dos efluentes produzidos, ou seja, um esgoto mais diluído, sem tantos sólidos e material orgânico particulado. A Tabela 3 apresenta os valores médios obtidos para a caracterização do esgoto bruto e do efluente tratado, assim como suas respectivas eficiências.

Tabela 3: Valores médios, mínimos e máximos para esgoto bruto, efluente tratado e eficiência de remoção.

\begin{tabular}{|c|c|c|c|}
\hline Parâmetros & Esgoto Bruto & Esgoto tratado & Remoção \\
\hline \multirow[t]{2}{*}{ Temperatura $(\stackrel{\circ}{ } \mathrm{C})$} & 26,7 & 26,2 & $\mathrm{~N} / \mathrm{A}$ \\
\hline & $25,2-28,2$ & $24,4-28,7$ & \\
\hline \multirow[t]{2}{*}{$\mathrm{pH}$} & 8,4 & 8,0 & N/A \\
\hline & $7,9-8,7$ & $7,5-8,9$ & \\
\hline \multirow[t]{2}{*}{ Condutividade elétrica $(\mu \mathrm{S} / \mathrm{cm})$} & 1481 & 2170 & N/A \\
\hline & $840-1766$ & $1920-2430$ & \\
\hline \multirow[t]{2}{*}{ Sólidos suspensos (mg/L) } & 213,7 & 140,6 & $34 \%$ \\
\hline & $24-418$ & $4-530$ & \\
\hline \multirow[t]{2}{*}{ Alcanilidade total (mgCaCO3/L) } & 273,3 & 239,2 & $13 \%$ \\
\hline & $150-375$ & $50-750$ & \\
\hline \multirow[t]{2}{*}{ Coliformes termotolerantes (NMP/100mL) } & $8,0 \times 10^{7}$ & $4,3 \times 10^{7}$ & $47 \%$ \\
\hline & $3,3 \times 10^{6}-3,4 \times 10^{8}$ & $1,7 \times 10^{6}-2,4 \times 10^{8}$ & \\
\hline \multirow[t]{2}{*}{ Fósforo total (mg/L) } & 13,7 & 7,6 & $44 \%$ \\
\hline & $12,8-15,1$ & $9,8-5,5$ & \\
\hline \multirow[t]{2}{*}{ Ortofosfato solúvel (mg/L) } & 11,4 & 6,7 & $41 \%$ \\
\hline & $9,5-12,6$ & $8,9-4,5$ & \\
\hline \multirow[t]{2}{*}{ Nitrogênio amoniacal (mg/L) } & 123,8 & 134,6 & N/A \\
\hline & $52,7-223$ & $100,9-183$ & \\
\hline \multirow[t]{2}{*}{ Nitrogênio orgânico (mg/L) } & 47,6 & 11,6 & $76 \%$ \\
\hline & $0,1-152$ & $0,1-38$ & \\
\hline \multirow[t]{2}{*}{ NTK (mg/L) } & 171,5 & 146,2 & $15 \%$ \\
\hline & $56-260$ & $128-186$ & \\
\hline \multirow[t]{2}{*}{$\mathrm{DQO}(\mathrm{mg} / \mathrm{L})$} & 413,0 & 103,2 & $75 \%$ \\
\hline & $54,3-797$ & $30,5-181$ & \\
\hline \multirow[t]{2}{*}{ Sódio (ppm) } & 115,0 & 115,0 & $0 \%$ \\
\hline & $110-120$ & $90-155$ & \\
\hline \multirow[t]{2}{*}{ Potássio (ppm) } & 111,0 & 110,0 & $1 \%$ \\
\hline & $106-117$ & $107-112$ & \\
\hline \multirow[t]{2}{*}{ Cálcio (ppm) } & 8,0 & 8,0 & $0 \%$ \\
\hline & $7,9-8,3$ & $7,8-8,3$ & \\
\hline
\end{tabular}

O sistema de tratamento de efluentes do campus é anaeróbio, por isso não tem a remoção da amônia, mas a adição, devido à ocorrência da amonificação, que promove a conversão do nitrogênio orgânico em amônia e, por consequência, o valor de eficiência do NTK tende a ser baixo. Estudos sobre a remoção biológica de nitrogênio mostraram que, apesar de normalmente 
determinados gêneros de bactérias autotróficas oxidarem a amônia, o nitrito e outras bactérias, posteriormente a nitrato, e de bactérias heterotróficas reduzirem nitrato a nitrito, e este a nitrogênio gasoso, tendo-se material orgânico como redutor, nem sempre isso ocorre, sendo possível também outras formas alternativas de remoção de nitrogênio (AUN, 2007).

Nesse sentido, a DQO apresentou uma maior eficiência em virtude de o esgoto ter característica doméstica, favorecendo a transformação dos componentes orgânicos em biogás. No entanto, os resultados poderiam ter sido melhores, o que não foi possível graças à falta de limpeza, de manutenção e de vários problemas de operação. Durante todo o funcionamento do campus (desde 2015), as ETEs nunca foram esgotadas e a operação foi precária, divergindo das recomendações do fabricante, conforme Manual da HemFibra de Instalação, Operação e Manutenção ETE Digestor e Filtro Anaeróbio $15,0 \mathrm{~m}^{3}$ até $75,0 \mathrm{~m}^{3}$ - ECOFIBER ${ }^{\circledR}$, o qual menciona que, para esse tipo de tratamento, é indicado que o sistema passe por um esgotamento pelo menos uma vez ao ano.

De acordo com a Figura 9, os resultados da remoção de sólidos suspensos são consideráveis, no entanto, poderiam ter sido melhores conforme se espera para esse tipo de sistema, que pode alcançar eficiências de remoção de até 90\% para sólidos suspensos (CHERNICHARO, 2016). Embora o sistema tenha um decanto digestor, nele já estão contidos muitos sólidos retidos, impedindo-o de apresentar uma maior eficiência na remoção dos sólidos suspensos. Além disso, as características do efluente tratado demonstram a necessidade de se realizar um pós-tratamento desse efluente, a fim de remover contaminantes e recuperar produtos, como, por exemplo, nitrogênio e fósforo. Tal medida pode favorecer o reúso desses efluentes para fins menos nobres.

Os resultados obtidos na avaliação do quantitativo de coliformes termotolerantes na parte aérea das plantas irrigadas com efluente tratado apresentaram um decaimento significativo conforme se observa na Figura 8. Nos dois primeiros dias de suspensão da irrigação, praticamente não houve morte bacteriana, no entanto, no terceiro dia, verificou-se um decaimento bacteriano de 99,9993\%, resultando em uma concentração de coliformes termotolerantes de 300 NMP/100 $\mathrm{ml}$. 
Figura 8: Decaimento bacteriano de coliformes termotolerantes na parte aérea de espécimes de milho (Zea mays) em função do tempo sem irrigação.

\section{DECAIMENTO BACTERIANO PARA COLIFORMES TERMOTOLERANTES}

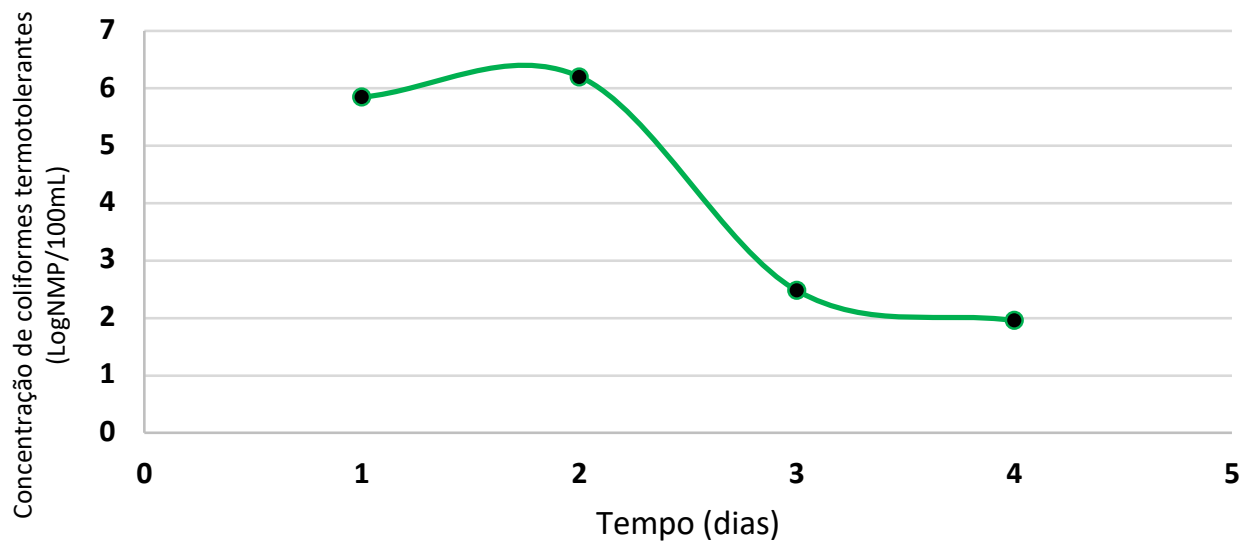

A partir da pesquisa, constatou-se que as plantas irrigadas com água potável não apresentaram concentrações de coliformes termotolerantes detectáveis, já que tais organismos estão ausentes na água de abastecimento, conforme laudos de qualidade fornecidos pela CAERN. Em relação aos parâmetros agronômicos, verificou-se que as plantas irrigadas com efluente se desenvolveram mais rapidamente quando comparadas às plantas irrigadas com água potável, apresentando uma diferença de $36 \%$ de altura entre elas. Para a produção de massa seca, 0 aumento foi de cerca de $153 \%$.

Tabela 4: Alturas de plantas (AP) e massa seca da parte aérea (MS) do milho (Zea mays) irrigado com efluente tratado e água potável.

\begin{tabular}{ccccccccccc}
\hline Água usada & \multicolumn{4}{c}{ Alturas de plantas (cm) } & \multicolumn{5}{c}{ Massa seca (g) } \\
\cline { 2 - 10 } na irrigação & Ind. 1 & Ind. 2 & Ind. 3 & Ind. 4 & Média & Ind. 1 & Ind. 2 & Ind. 3 & Ind. 4 & Média \\
\hline Água potável & 0.91 & 0.93 & 1.00 & 0.98 & $\mathbf{0 . 9 6}$ & 24.04 & 17.97 & 14.34 & 19.48 & 18.96 \\
Efluente & 1.31 & 1.17 & 1.24 & 1.50 & $\mathbf{1 . 3 1}$ & 58.36 & 49.63 & 40.29 & 43.96 & $\mathbf{4 8 . 0 6}$ \\
\hline
\end{tabular}

\section{CONCLUSÕES}

Diante dos resultados encontrados, conclui-se que a fertirrigação com efluente tratado é uma atitude sustentável que mostra eficiência quando relacionada ao processo mais comum de irrigação, com água potável ou bruta. Se usado de forma equivocada, pode expor a saúde humana 
a riscos, mas é possível se preservar e respeitar o tempo necessário para manter contato direto com a planta, dificultando a contaminação após a suspensão da irrigação.

É importante ressaltar que os resultados apresentados neste trabalho foram realizados em apenas uma ETE devido a problemas operacionais identificados nas demais, tais como: excesso de gordura e sólidos grosseiros no tratamento preliminar, falta de esgotamento do sistema, vazamentos e baixa vazão. Desse modo, foi necessária a continuidade do monitoramento, estendendo-se para as demais estações de tratamento do campus São Paulo do Potengi.

Em síntese, obteve-se resultados satisfatórios, os quais se encontram em faixas esperadas para esse tipo de sistema. Alguns parâmetros são de suma importância para a fertirrigação, como: coliformes termotolerantes, que tiveram uma remoção de 47\%; nitrogênio orgânico, com 76\%; e DQO, com 75\%. Já em relação ao crescimento das plantas, foi concluído que o milho irrigado com a solução de $100 \%$ de efluente obteve um crescimento acima de $36 \%$ e ganho de mais de $153 \%$ de biomassa seca em relação à cultura irrigada com água potável, gerando economia no uso de água potável e acelerando o crescimento vegetal.

Além disso, as características do efluente final demonstram que, caso seja aplicado um póstratamento, a qualidade do esgoto tratado pode melhorar em termos microbiológicos e garantir usos mais restritos do efluente tratado para a agricultura. Nas condições atuais, para se fazer o reúso agrícola desse efluente, é fundamental que o manejo do solo e do volume de irrigação seja controlado.

\section{REFERÊNCIAS BIBLIOGRÁFICAS}

AMARAL, X. S. Avaliação de sistemas de tratamento de esgoto e aproveitamento de água de chuva em unidades educacionais. Dissertação de mestrado em Engenharia Sanitária (UFRN- Natal). 2015.

ANA - AGÊNCIA NACIONAL DE ÁGUAS. Disponível em: < https://www.ana.gov.br/>. Acessado em 14 nov 2019.

APHA, AWWA E WEF - AMERICAN PUBLIC HEALTH ASSOCIATION; AMERICAN WATER WORKS ASSOCIATION; WATER ENVIRONMENT FEDERATION. Standard methods: for the examination of water and wastewater. 23.ed. Washington: American Public Health Association, 2017.

AUN, Mariana Vivolo. Estudo de remoção de nitrogênio via nitrito e via nitrato em sistemas de lodo ativado alimentado por despejo com elevada concentração de fenol. São Paulo, 2007. Tese (Engenharia Hidráulica) - Universidade de São Paulo. São Paulo.2007. 
BRASIL - Ministério da Agricultura, Pecuária e Abastecimento. Disponível em: < www.agricultura.gov.br/noticias/produtividade-da-agropecuaria-cresce-3-36-aoano/copy_of_produtividade_2019_word.docx>. Acessado em: 13 nov 2019.

BRASIL. Ministério Do Meio Ambiente. Conselho Nacional De Recursos Hídricos. Resolução no 54. DOU em 09/03/06. Disponível em: Universidade Estadual Paulista (Mestrado). Acesso em: 12 mar. 2013.

CHERNICHARO, L. A. C. Princípios do Tratamento Biológico de Águas Residuárias- Reatores Anaeróbios. 2. ed. Belo Horizonte: UFMG, 2016.

FELIPE, José Lacerda Alves. CARVALHO, Edílson Alves de. ROCHA, Aristotelina P. Barreto. Atlas Rio Grande do Norte: espaço geo-histórico e cultural. João Pessoa: GRAFSET, 2004.

HESPANHOL, Ivanildo. Aspectos ambientais, sociais e jurídicos do reuso da água. Reuso da água, São Paulo, SP, 2002. Disponível em: https://www.researchgate.net/publication/305306332. Acesso em: 12 mar. 2019.

IBGE - INSTITUTO BRASILEIRO DE GEOGRAFIA E ESTATÍSTICA. Disponível em: < https://www.ibge.gov.br/>. Acessado em 10 nov 2019.

METCALFF and EDDY, INC. (2017). Tratamento de efluentes e recuperação de recursos. 5a Edição, Mc Graw-Hill, New York.

MORISON, J. I. L.; BAKER, N. R.; MULLINEAUX, P. M.; DAVIES, W. J. Improving water use in crop production. Philosophical Transactions of the Royal Society B: Biological Sciences, v.353, p.639$658,2008$.

OLIVEIRA, Eduardo Luiz de (Org.). Manual de Utilização de Águas Residuárias em Irrigação. 1ạ Botucatu: Fepaf, 2012.

RIBEIRO, Jaqueline Cardoso. Reuso de efluentes na agricultura. 2013. Tese (Mestre em Engenharia Civil e Ambiental - Saneamento Ambienta) - Universidade Estadual Paulista (UNESP), São Paulo, SP, 2013.

Disponível

em:

http://wwwp.feb.unesp.br/eduoliv/Seminarios2013/?action=download\&file=LOphcXVlbGluZS9SR VVTTyBOQSBBR1JJQ1VMVFVSQSBGSU5BTC5WZGY. Acesso em: 12 mar. 2019.

ROCHA, F. A.; SILVA, JO da; BARROS, F. M. Reuso de águas residuárias na agricultura: A experiência israelense e brasileira. Enciclopédia Biosfera, v. 6, p. 1-9, 2010.

TONETTI, A.L.; CORAUCCI FILHO, B.; BERTONCINI, E.I.; OLIVEIRA, R.A.; STEFANUTTI, R. (2010) Avaliação de um sistema simplificado de tratamento de esgotos visando a utilização em áreas rurais. Revista Brasileira de Engenharia Agrícola e Ambiental, v. 14, n. 2, p. 227-234. 